\title{
The potential of solar photovoltaic systems for residential homes in Lagos city of Nigeria
}

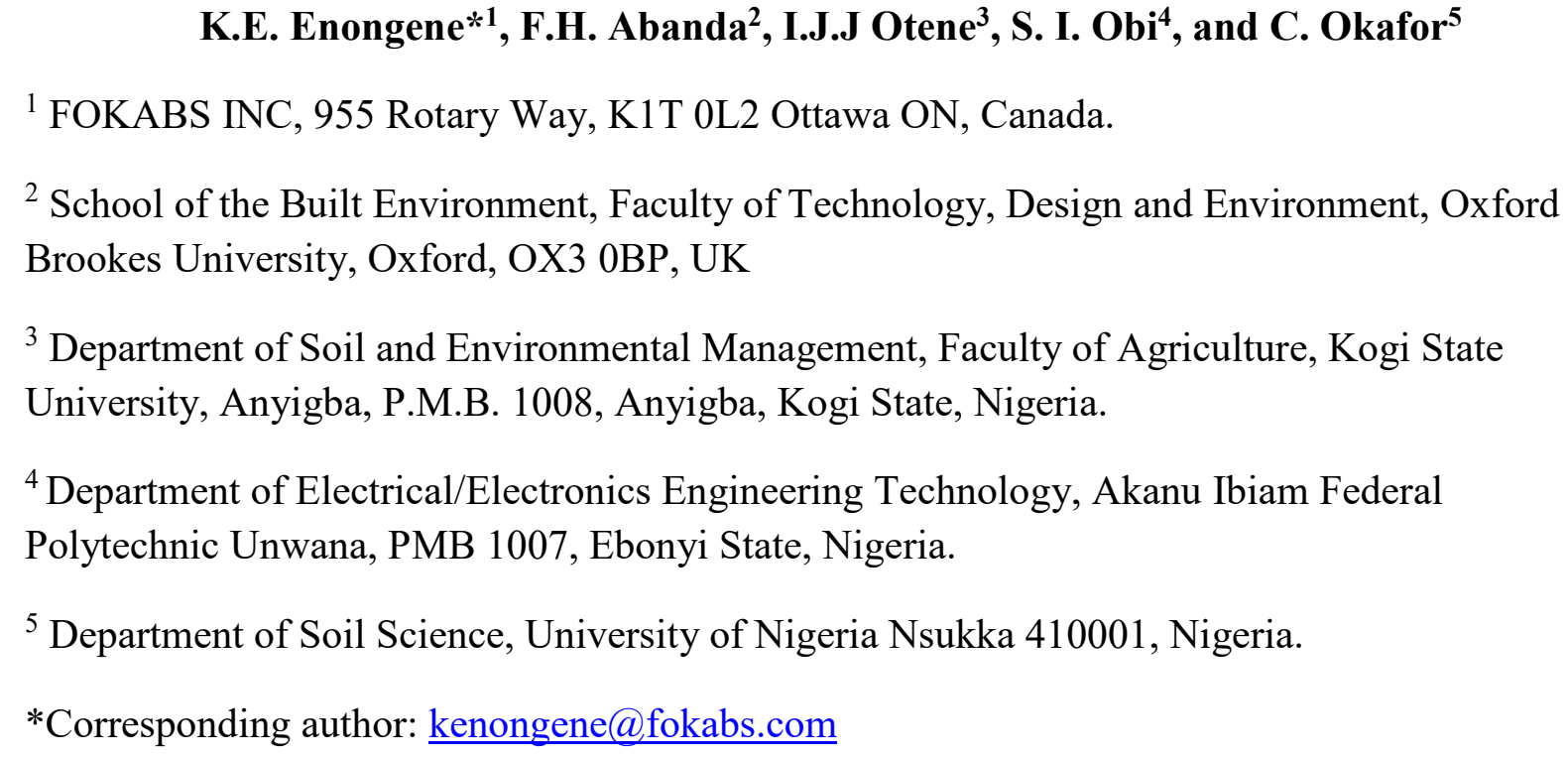

Abstract: The development and use of solar photovoltaic (PV) technologies worldwide is considered crucial towards fulfilling an increasing global energy demand and mitigating climate change. However, the potential of a solar PV-system is location specific, influenced by the local solar resource, energy demand and cost among other factors. The main aim of this study is to conduct a detailed assessment of the potential of solar PV-systems in residential buildings in Lagos Metropolitan Area, Nigeria. Nigeria has enormous solar energy potential, it is the most populous country in Africa and occupies a significant place in the development of Africa. Yet, it is a county with one of the lowest per capita electricity consumption in the world - at $149 \mathrm{kWh}$ per capita for a population of about 170 million, about 7\% of Brazil's and 3\% of South Africa's. To achieve this goal, this study employed the survey of 150 residential buildings in three local government areas (LGAs) in Lagos State, Nigeria to obtain electric load data. HOMER Pro was used to size the PV-systems and to determine the levelized cost of electricity (LCOE). The computed energy results of the study for the base case scenario revealed the PV array, lead acid 
battery and the converter (inverter) of the PV-systems to be in the following range: 0.3 to $76 \mathrm{~kW}$;

272 to $176 \mathrm{kWh}$; and 0.1 to $13.2 \mathrm{~kW}$ respectively. Economic analysis revealed a LCOE of the systems in the range of $0.398 \mathrm{USD} / \mathrm{kWh}$ to $0.743 \mathrm{USD} / \mathrm{kWh}$. The use of PV-system generated

29 electricity in the dwellings has potential for an annual reduction of greenhouse gas emissions in the range of $31.24 \mathrm{kgCO}_{2}$ eq to $7456.44 \mathrm{kgCO}_{2}$ eq. Clearly, the use of solar PV systems in

31 residential buildings possesses potentials for enabling Nigeria to attain its climate change mitigation targets indicated in her National Determined Contributions (NDCs).

Key words: Energy; Nigeria; renewable energy; photovoltaic; residential buildings

Provision of reliable and adequate energy services in an environmentally friendly manner and in

37 conformity with social and economic developmental needs is important for the attainment of sustainable development goals (Vera \& Langlois, 2007). Energy is important for the eradication of poverty, for driving national economies, for raising living standards and improving human welfare. The importance of energy is recognized in the adopted sustainable development goals

41 (SDGs) of the United Nations with the seventh of the 17 goals geared at ensuring access to 42 affordable, reliable, sustainable and modern energy for all (United Nations, 2015). Most patterns 43 of energy supply and use around the world is unsustainable. In most parts of the globe, economic 44 development is limited due to a lack of reliable and secure supply of energy. An approximate 2.7 45 billion people in the world rely on the use of traditional biomass for cooking (International 46 Energy Agency, 2010) while an estimated 1.7 billion people lack access to electricity. Between 472000 and 2010, annual anthropogenic greenhouse gas emissions (GHG) increased by 10 $48 \mathrm{GtCO}_{2}$ eq with energy supply accounting for $47 \%$ of the increase (IPCC, 2014), implying that the 
energy sector makes a significant contribution to climate change. According to Su et al. (2016),

50 economic development and population growth in cities alongside increased energy consumption

51 with consequent environmental problems have retarded sustainable development in urban areas.

52 In spite its large population and strategic role in Africa, Nigeria exhibits the aforementioned

53 hallmarks of energy poverty and negative environmental impacts that retard development. The

54 reasons for the characterization of Nigeria in the preceding sentence constitute the choice of it as

55 a case study region in this study. This will be discussed in the ensuing paragraph.

56 Nigeria's per capita electricity consumption is one of the lowest in the world - at $149 \mathrm{kWh}$ per

57 capita for a population of about 170 million, about $7 \%$ of Brazil's and 3\% of South Africa's.

58 Furthermore, a large proportion of the Nigerian population lives in rural areas, where most of the

59 villages are not connected to the grid due to lack of infrastructure (Mellersh, 2015). Nigeria's per

60 capita power consumption of less than $150 \mathrm{kWh}$ is one of the lowest in Africa, lower than those

61 of many less developed countries, including the Republic of Congo, Zimbabwe, Yemen and

62 Togo (Olaniyi, 2017; Oluseyi et al., 2016). In Nigeria, the generation of electricity dates back to

631896 when electricity was first generated in Lagos (Sambo, 2008a). Notwithstanding that

64 electricity has been present in the country for more than a century, the development of the

65 electricity sector has been occurring at a very slow rate. The demand of electricity in Nigeria

66 exceeds supply which is epileptic in nature irrespective of the enormous natural resources

67 endowed by the country which could be employed in the generation of electricity. According to

68 Sambo (2008a), 20 years prior to 1999, the Nigeria energy sector witnessed unsubstantial

69 infrastructural development investment since existing plants were not adequately maintained

70 while new ones were not commissioned. The author further recounted that the low investment in 
71 the energy sector in 2001 resulted to a reduction in the estimated installed generation capacity

72 from $5600 \mathrm{MW}$ to $1750 \mathrm{MW}$, far lower than the load demand of $6000 \mathrm{MW}$.

73 The consumption of electricity in Nigeria is dominated by the residential sector (Azodo, 2014)

74 with lighting being a major contributor. Due to the unreliable nature of the electricity supplied

75 from the grid, it is a common practice for households to use standby generators or kerosene

76 lamps to meet their lighting needs or as an alternative for lighting (Ahemen et al., 2016). The use

77 of diesel generators in residential buildings in Nigeria are not only a source of stress and fatigue

78 to household members as a result of the noise produced but as well constitutes a source of GHG

79 emissions (Oyedepo, 2012). Efforts towards addressing the energy situation by the Nigerian

80 government have been geared towards building more power plants but irrespective of the efforts

81 and financial resources invested, energy generation on average has remained below $4000 \mathrm{MW}$

82 (Olaoye et al., 2016). The integration of renewable energy into the current energy mix of Nigeria

83 can achieve the required $60 \mathrm{GW}$ needed to place Nigeria in the category of an industrialized

84 nation without significant increase in environmental harm associated with pollution. However,

85 in order to adopt PV-system, it is imperative to establish the requirements and viability of such

86 an initiative especially on a wider scale. The aim of this study is to conduct a detail study of the

87 potential of solar PV-systems in Lagos Metropolitan Area, Nigeria. To achieve this aim, the

88 following objectives will need to be attained:

- Identify the different household energy consumption devices and patterns in some

$90 \quad$ selected regions;

91 - Investigate the potential of solar photovoltaic systems in Nigeria;

92 - Investigate the variation of the potential between main housing types in three local

93 government areas in Lagos Metropolitan Area, Nigeria. 
2. Renewable energy studies in Nigeria: An overview

\subsection{PV-system feasibility studies}

96 Several studies about renewable energy sources in Nigeria could be used to inform the

97 generation of electricity as a way forward to close the energy deficit gap in the country. These

98 studies among others include: the investigation of the potential of the agricultural sector as a

99 source of renewable energy in Nigeria by Elum et al. (2016), Akuru et al. (2017) discussed how

100 Nigeria could transition towards 100\% renewable energy, Olaoye et al. (2016) studied the

101 energy crisis in Nigeria and the need for renewable energy mix, Diemuodeke et al. (2016)

102 conducted an assessment of hybrid renewable energy systems for coastline communities in

103 Nigeria, Osunmuyiwa et al. (2016) studied the conditions necessary for the transition and

104 adoption of renewable energy in Nigeria, Olatomiwa et al. (2016) conducted a study on hybrid

105 renewable power supply for rural health clinics in Nigeria, Akorede et al. (2016) studied the

106 current status and outlook of renewable energy development in Nigeria while Riti \& Shu (2016)

107 conducted a study on renewable energy, energy efficiency and eco-friendly environment in

108 Nigeria. What emerges from the aforementioned studies is that Nigeria is endowed with

109 renewable energy resources including solar which if well exploited will enable the country to

110 meet its energy demand and overcome the existing energy crisis. Nigeria is endowed with

111 hydropower, biomass, solar, wind, geothermal, wave and tidal energy potentials that can be

112 employed in the generation of electricity (Akuru et al., 2017). Of the renewable energy

113 alternatives, solar appears the most promising and important source for electricity generation in

114 the future for both rural and urban areas (Okoye et al., 2016) and this could be attributed to its 115 apparent abundance and generation potential. For instance, based on the 2030 renewable energy 116 generation target for Nigeria, solar is envisaged to account for over half of the projected energy 
117 to be generated (Table 1). The amount of energy that can be generated from a PV-system 118 depends on the local solar resource and the conversion efficiency of the system adopted. Nigeria 119 is located within a high sunshine belt and solar radiation is fairly well-distributed within the 120 country, with an average solar radiation that varies from $12.6 \mathrm{MJ} / \mathrm{m}^{2} /$ day in the coastal latitudes 121 to an estimated $25.2 \mathrm{MJ} / \mathrm{m}^{2} /$ day in the Far North part of the country (Akuru et al., 2017). Olaoye 122 et al. (2016) opine that the use of $1000 \mathrm{~W}$ solar power systems on rooftops of one million 123 Nigerian homes will result in a cumulative power production of $7000 \mathrm{MW}$ of which can translate 124 into a $45 \%$ addition to the present electricity per capita consumption.

Table 1: 2030 renewable energy target for Nigeria (Source: Sambo, 2008b).

\begin{tabular}{|l|l|l|l|l|l|l|l|}
\hline Resource & $\begin{array}{l}\text { Solar } \\
\text { PV }\end{array}$ & $\begin{array}{l}\text { Solar } \\
\text { Thermal }\end{array}$ & Wind & $\begin{array}{l}\text { Large } \\
\text { Hydro }\end{array}$ & $\begin{array}{l}\text { Small } \\
\text { Hydro }\end{array}$ & Biomass & Total \\
\hline Long term (MW 2030) & 36,750 & 15,500 & 50 & 11,250 & 3,500 & 1,300 & 63,345 \\
\hline
\end{tabular}

127 Several PV-related studies have been conducted in Nigeria including: solar energy potentials 128 (Fadare, 2009; Okoye et al., 2016; Giwa et al., 2017; Ikejemba \& Schuur, 2016); solar energy 129 related policies (Ozoegwu et al., 2017); environmental footprints of electricity generation from 130 solar PV (Akinyele et al., 2017); and technical and or economic feasibility related study of solar 131 PV-systems (Bukar et al., 2017; Njoku et al., 2016; Okoye \& Tylan, 2017; Adaramola \& 132 Oyewola, 2014; Ajoa et al., 2011; Adaramola, 2014; Oparaku, 2002; Akpan et al., 2013). From 133 the aforementioned studies, it could be gathered that Nigeria has a good solar potential which 134 could be harnessed to allay the energy crisis of the country and reduce GHG emissions. 135 However, the cost of electricity generated from PV-systems in the country is not competitive to 136 that supplied from the grid. From literature search, most of the PV-related design and techno137 economic assessment conducted in Nigeria have been geared towards off-grid electrification of 
138 rural communities with very little focus on residential buildings in grid-connected cities in the 139 country. The existing studies on the design and use of stand-alone solar PV-systems in 140 residential buildings concentrate on a single building and do not cover the different building 141 types. For instance, Guda \& Aliyu (2015), Okoye at al. (2016), Ayodele \& Ogunjuyigbe (2015),

142 Adaramola et al. (2014) and Ogunjuyigbe et al. (2016) considered just a single (typical) building 143 in its design for a PV-system for a residential building in Nigeria. While their findings 144 demonstrates the potential of solar PV systems in supplying energy to meet the energy demand 145 of the respective buildings, the results cannot be assumed for other building types since energy 146 load differ among dwellings. Our study is innovative in that it covers the different categories of 147 residential buildings and employs a bigger sample size of 150 buildings from three different 148 Local Government Areas (LGAs).

\subsection{Energy policies in Nigeria}

150 Nigeria had no comprehensive energy policy before 2003 (Shabaan and Petinrin, 2014). The

151 country had separate policy documents for the different energy sub-sectors including: solid 152 minerals, oil, gas and electricity (Sesan, 2008). The Nigerian energy policy document came into 153 existence in 2003 to serve as a roadmap for a better energy future for Nigeria (Ajayi \& Ajayi, 154 2013). This energy policy document envisaged to ameliorate the energy sector of the country by 155 taking the following steps: commercialization and privatization of the successor Power Holding 156 Company of Nigeria (PHCN) companies, the commissioning of new power plants and 157 distribution entities, inflow of private sector investment and creating an enabling environment 158 for the development of a competitive electricity market. 
159 The analysis of Nigeria's energy demand and supply projections from 2010-2030 was conducted 160 by Sambo (2008a) using Model for the Energy Supply Strategy Alternatives and their General 161 Environmental Impact (MESSAGE). Fuels inputted for the optimization were natural gas, hydro, 162 solar, coal, nuclear, and wind. The future installed electricity generation capacity by fuel for 1632030 is presented in Figure 1. The results reveals that of the consumed electricity from fuel types 164 in Nigeria, solar is expected to produce $8.3 \%$.

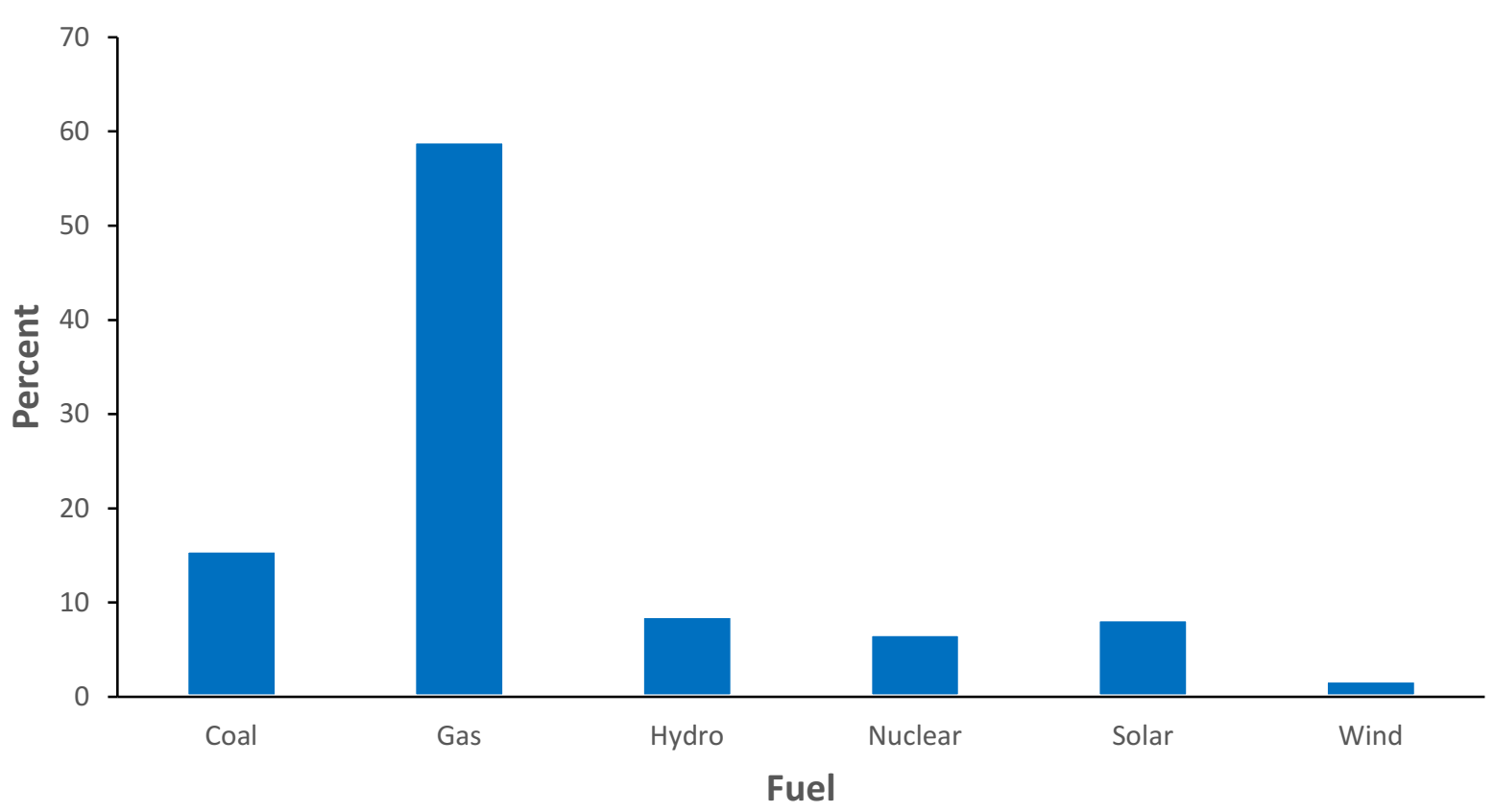

Figure 1: The future installed electricity generation capacity by fuel (Reference Case \%, Source: Sambo, 2008a).

Nigeria's monthly per capita electricity consumption is estimated to be $12 \mathrm{kWh}$ (International Energy Agency - IEA, 2017). This national per capita electricity consumption is lower compared to $27 \mathrm{kWh}$ reported by Olaniyan et al. (2018). In South West region where Lagos is located, per capita residential electricity consumption per month is $23 \mathrm{kWh}$ (National Bureau of Statistics NBS, 2016). Average electricity price in South West Nigeria is 6 US cents/kWh (NBS, 2017; Nigerian Electricity Regulatory Commission - NERC, 2017; Olaniyan et al., 2018). 
175 Nigeria has set a renewable energy target in the transport and electricity sectors (IRENA, 2015).

176 With respect to electricity generation, the country has a target of electricity generation from 177 renewable sources set at $9.74 \%, 18 \%$ and $20 \%$ by 2015, 2020 and 2030 respectively (Bamisile 178 et al., 2017). Electricity generation from solar energy alone stands at $1.26 \%, 6.92 \%$ and 15.27 $179 \%$ for 2015,2020 and 2030 respectively while the target of renewable electricity from solely 180 solar is at $12.96 \%, 38.43 \%$ and $76.36 \%$ for 2015,2020 and 2030 respectively indicating that 181 solar will dominate in the long-term. The revised version (November 2012) of the REMP 182 provides a list of economic and financial instruments/incentives that should be employed in order 183 to reduce the high initial investment cost of renewables so as to bolster the penetration of 184 renewables into the energy supply mix of the nation (Ozoegwu et al., 2017). These energy targets 185 and supportive renewable energy policies highlighted in the REMP are not yet binding since the 186 REMP is yet to be approved and signed into a law by the National Assembly and the Executive 187 respectively. However, the National Renewable Energy and Energy Efficiency Policy (NREEEP) 188 developed in 2013/2014 by the Federal Ministry of Power and approved in 2015 by the Federal 189 Executive Council stands in as a binding document for the REMP (Nigerian Energy Support 190 Programme, 2015). The solar electricity target of the NREEEP stands at $117 \mathrm{MW}, 1343 \mathrm{MW}$ and 1916831 MW by 2015, 2030 and 2030 respectively. In an attempt to create a conducive environment 192 that will promote the entry of renewable energy into Nigeria, NREEEP empowers relevant 193 government ministries and federal government agencies and departments to adopt and develop 194 any of the following instruments: mandatory or voluntary renewable portfolio standards, net 195 metering framework, feed-in-tariffs, adoption of a public benefit funds, power production tax 196 credits, provision of capital grants, tax holidays and exemptions and other incentives for 197 renewable energy projects, bidding rounds through national renewable energy independent 
power producer procurement program and generation disclosure requirement. According to the

199 Renewables 2015 global status report, support policies for renewable energy in Nigeria include:

200 feed-in-tariffs, biofuel obligation/mandate, public investments, loans or grants, reductions in

201 sales, energy, $\mathrm{CO}_{2}$, value-added tax (VAT), or other taxes and capital subsidy, grant or rebate.

\section{Characteristics of favourable environment for the adoption and use of solar PV-Systems}

203 Generally, the adoption and use of PV systems for electricity generation in residential homes

204 mainly depend on knowledge of the environmental benefit of PV systems over other source of

205 fuels for electricity generation especially fossil fuel. The consciousness of the population on the 206 environmental benefit of using PV systems over fossil fuel constitutes an enabling environment

207 for its adoption (Palm \& Tengvard, 2017). Some households adopt PV systems as a way to 208 promote environmental sustainability. Furthermore, the initial cost of investment (purchase and 209 installation) of PV systems in residential homes may be high compared to electricity supply from 210 the grid system. Vasseur and Kemp (2015) reported that the competitiveness of the price of PV 211 generated electricity with the electricity supplied from the grid plays an important role in its 212 adoption and use. Hence, PV adoption and use will be favourable where electricity from PV is 213 competitive with that supplied from the grid. Also, reduced investment cost of solar PV and 214 increased dissemination of knowledge on its environmental benefits among the population are 215 favourable conditions for their adoption and use.

\section{Methodology}

217 This study surveyed residential buildings from three Local Government Areas (LGAs): Kosofe, 218 Oshodi and Alimosho in Lagos Metropolitan Area, Lagos State of Nigeria. The survey was 219 conduced using a structured questionnaire. The approach consisted of using purposeful 
220 sampling. The purposive sampling enabled the selection of units based on particular purposes

221 linked to achieving research objectives of the study as well as representativeness and

222 comparisons among different types of cases. Lagos is divided into five Administrative Divisions

223 (Lagos, Epe, Badagry, Ikorodu and Ikeja) which are further divided into 20 Local Government

224 Areas (LGAs) and 37 Local Council Development Areas (LCDAs). The "Lagos Metropolitan

225 Area" also known as Metropolitan Lagos contains about $85 \%$ of the population of Lagos State,

226 and includes semi-rural areas. The three LGAs (Alimosho, Kosofe, and Oshodi) selected for this

227 study fall under the five largest LGAs out of the 16 LGAs in Metropolitan Lagos - 2006

228 population census (National Population commission Nigeria, 2010). In each of the LGAs, the

229 different residential building types were identified and an equal number (10) of each building

230 type were surveyed for the collection of data. In each household surveyed, the questionnaire

231 administrator together with a household member completed the energy audit section of the

232 questionnaire while the time-of-use diary section of the questionnaire was left with the

233 household for completion. The data from the time-of-use diary was used in Microsoft Excel for

234 the computation of the hourly electricity load profile for the seven days of the week for each

235 building surveyed. The hourly energy load (in watts) for each building was obtained by summing

236 up the power rating of all the appliances used during the 24 hours period of the day and the

237 obtained value converted to $\mathrm{kWh}$ by dividing by 1000 . The daily load profile for each dwelling

238 was obtained as an average of the load profile for the seven days of the week. The technical,

239 economic and environmental potential for the use of solar PV-systems for the onsite generation

240 and use of electricity to meet the electricity needs of the buildings was analyzed. The technical

241 and economic assessments were conducted using HOMER Pro and the economic analysis was

242 based on the Levelized Cost of Electricity (LCOE). Sensitivity analysis was performed using 
243 HOMER Pro by varying the economic parameters (inflation and discount rates) and the solar

244 PV-system sizing parameters.

\section{Description of survery and analysis}

\section{$246 \quad$ 4.1. Household surveys}

247 Jiboye (2014) reported five categories of residential buildings in Nigeria: duplex, single family

248 bungalow, traditional court yard, flat/apartment dwelling and 'face-me-I-face-you'. These five 249 categories of buildings were considered for this study. Hence, while the study is conducted for

250 Lagos, results for each building type obtained in this study could be relevant for similar building 251 types in other parts of Nigeria. In each of the LGAs, 50 households (10 per building category)

252 were randomly sampled with the use of a questionnaire amounting to a total of 150 households

253 for the entire study (Table 2). The number of local governments and buildings selected in Lagos

254 Metropolitan Area were based on the existing challenges to sustainable development in these 255 areas such as limited and inefficient power supply from the grid system, environmental, 256 sociocultural, economic and administrative/legislative problems reported in previous studies 257 (Oduwaye, 2009; Otegbulu, 2011; Adama, 2017). The questionnaire was structured into four 258 different sections. Section 1 was designed to obtain socio-econimic data of the households, 259 section 2 was geared at capturing characteristics of the buildings, section 3 was desgined to 260 obtain information about the electrical applicances used in the surveyed buildings while section 4 261 was designed as a time-of-use diary to capture information related to the time and duration of use 262 of the different appliances in the buildings, as used by Enongene et al. (2017) and Manjia et al. 263 (2016). The survey had a response rate of $100 \%$. This high response rate was due to the fact that 264 research assistants walked through the neigbourhood, handed the questionnaire and return later 
to collect. The research assistant provided help to those residents who striuggled with completing the questionnaires.

267 Table 2: Selection of number of buildings in Local Government Areas

\begin{tabular}{|l|c|c|c|}
\hline Building type & Kosofe & Oshodi & Alimosho \\
\hline Duplex & 10 & 10 & 10 \\
\hline Simple family bungalow & 10 & 10 & 10 \\
\hline Traditional court yard & 10 & 10 & 10 \\
\hline Flat/apartment & 10 & 10 & 10 \\
\hline 'Face-me-I-face-you' & 10 & 10 & 10 \\
\hline Total & 50 & 50 & 50 \\
\hline
\end{tabular}

LGA: Local Government Area

\subsection{Sizing of solar PV-system components}

\section{Computation of load profiles}

272 The energy load profile for the appliances for all the buildings surveyed was computed using

273 Excel spreadsheet. The hourly energy load (in $\mathrm{kWh}$ ) for each building was obtained by summing

274 up the power rating of all the appliances used at specific periods of the 24 hours of the day. The 275 daily load profile for each dwelling was obtained as an average of the load profile for the seven 276 days of the week. The minimum and maximum load of buildings employed in the sizing of the 277 systems is presented in Appendix A (see Data in Brief).

\section{System design}

279 A stand-alone PV-system was designed to meet the minimum and maximum load profile for 280 each building type per LGA. A total of 30 PV-systems were therefore designed.

281 For this design to be effected, site details or locations were edited in Homer Pro. In the case of 282 this study, the 3 locations or LGAs were edited separately. Other information edited into Homer 283 Pro were the minimum and maximum electric load profiles, PV-system components (battery, 
284 PV-system array and converter) technical and cost details and the solar resource data (Global

285 Horizontal Irradiation-GHI) for the study locations (LGAs).

286 Based on the edited data, HOMER Pro was used to conduct the simulation process by modelling

287 the behaviour of the system configuration each hour of the year in order to determine the

288 system's technical feasibility and life cycle cost. This includes the optimization of the system by

289 simulating different system configurations with the objective of searching for the system that

290 satisfies the technical constraints at the lowest life cycle cost. The base case scenario calculation

291 was performed based on the following: a minimum battery state of charge (SOC) of $40 \%, 0 \%$

292 maximum annual capacity shortage, 5\% discount rate, 2\% inflation rate and a PV-system

293 lifetime of 25 years. The capacity shortage was set at $0 \%$ in order to investigate the potential of

294 the system to serve $100 \%$ of the buildings' load while $40 \%$ battery SOC coincides with the

295 recommended depth of discharge of the battery bank that will safeguard its lifespan.

\section{Sensitivity analysis}

297 HOMER Pro was used to perform sensitivity analysis based on five different variables:

298 maximum annual capacity shortage, PV-system lifetime, minimum battery SOC, inflation and

299 discount rate in order to determine their effect on the system's LCOE. Table 3 presents the 300 sensitivity parameters used.

Table 3: Sensitivity parameters employed in the HOMER Pro modelling

\begin{tabular}{|l|c|c|}
\hline Sensitivity variable & Base case & Sensitivity case(s) \\
\hline Maximum annual capacity shortage & $0 \%$ & $5 \%, 10 \%$ and $15 \%$ \\
\hline Discount rate & $5 \%$ & $10 \%$ \\
\hline PV-system lifetime & 25 years & $\begin{array}{c}\text { 20 years and 30 years (e.g. } \\
\text { J.v.G Desert Module) }\end{array}$ \\
\hline Inflation rate & $2 \%$ & $5 \%$ \\
\hline Minimum battery SOC & $40 \%$ & $30 \%$ \\
\hline
\end{tabular}


303 The size (area) of the PV-system array for the different buildings was computed using equation 1 304 as purported by Birajdar et al. (2013).

$$
A_{P V}=\frac{L_{e l}}{H_{a v g} \times n_{p v} \times n_{b} \times n_{i} \times T_{C F}}
$$

306 Where APV represents the required PV-system array area in $\mathrm{m}^{2}$, $\mathrm{Lel}_{\mathrm{el}}$ is the required daily electric 307 load of the building in $\mathrm{kWh} /$ day, $\mathrm{H}_{\mathrm{avg}}$ is the location's average daily solar irradiation in $\mathrm{kWhm}^{-}$ $308{ }^{2} \mathrm{~d}^{-1}, n_{\mathrm{pv}}$ represent the PV panel efficiency in $\%, n_{\mathrm{i}}$ is the efficiency of the inverter in $\%$ while $\mathrm{T}_{\mathrm{CF}}$ 309 stands for the temperature correction factor, $n_{b}$ is the battery efficiency. The battery and inverter 310 efficiency were adopted from Abdul and Anjum (2015) as 85\% and 90\% respectively while the

$311 \mathrm{~T}_{\mathrm{CF}}$ was adopted from Caisheng and Nehrir (2008) as 80\%. It is important for the PV-system 312 area to be adjusted to take into consideration variation of the PV-system output over its lifetime 313 as a result of degradation. This adjustment is effected by dividing the PV-system area by the 314 module derate factor which accounts for PV-system output reduction due to the accumulation of 315 dust and degradation over time. A module derate factor of 0.9 was adopted from Sandia National 316 Laboratories (1995).

\section{4.3. Economic analysis}

318 HOMER Pro was employed in conducting the economic analysis using the information presented 319 in Table 4. The LCOE generated by the system using 2\% inflation rate and 5\% discount rate was 320 determined. The operation and maintenance cost was considered as $2 \%$ of the initial PV-system 321 module cost while the installation cost of the system was considered as $10 \%$ of the initial PV322 system module cost. 
Table 4: Cost of solar PV-system components (obtained from a local supplier)

\begin{tabular}{|l|c|}
\hline System component & Cost (USD) \\
\hline Module (100W monocrystalline) & 158 \\
\hline Charge controller (60 AMP) & 190 \\
\hline Battery (Deep acid lead, 83.3Ah) & 160 \\
\hline Inverter (1 kW) & 158 \\
\hline Total & 666 \\
\hline
\end{tabular}

324

325

\subsection{Environmental analysis}

327

328

329

330

A life cycle assessment (LCA) data for electricity generated from PV systems in Nigeria is used to estimate the environmental benefits or potentials of the PV-systems employed in this study. Since such information is scarce, the average LCA data of $162 \mathrm{gCO}_{2} \mathrm{eq} / \mathrm{kWh}$ of electricity generated from monocrystalline modules obtained by Sherwani et al. (2010) was adopted. From Brander et al. (2011), the emission associated with a kWh of electricity from the grid in Nigeria stands at $440 \mathrm{gCO}_{2}$ eq. The emission saving (Es) associated with the use of a $\mathrm{kWh}$ of electricity generated by the PV-systems employed in this study was computed using the approach employed by Abanda et al. (2016):

$\mathrm{Es}=\mathrm{EG}-\mathrm{EPV}=440 \mathrm{gCO}_{2} \mathrm{eq}-162 \mathrm{gCO}_{2} \mathrm{eq}=278 \mathrm{gCO}_{2} \mathrm{eq}$

Where EG represents emissions associated with a kWh of grid electricity while EPV represents emissions of a kWh of PV-system generated electricity. This implies that if a building uses a $\mathrm{kWh}$ of PV generated electricity rather than a $\mathrm{kWh}$ of electricity from the grid, an emission saving of $278 \mathrm{gCO}_{2}$ eq constituting a $63.2 \%$ emission reduction would be achieved. The daily emission saving that would result from the use of electricity from the PV-systems by the 
341 buildings was computed by simply multiplying the daily load of the buildings in kWh by 278

$342 \mathrm{gCO}_{2} \mathrm{eq}$.

\section{Analysis of results and discussion}

\subsection{Sources of energy and fuel consumption in buildings}

345 The main source of energy for all the building types in the study locations is diesel generators 346 and rechargeable lanterns which are charged either by the diesel generators or electricity from 347 the grid, accounting for $48.4 \%$ of the total source of energy available in the area. Our findings 348 concerning the use of diesel generators in residential buildings concord with the claim of 349 Ayodele \& Ogunjuyigbe (2015) that almost every household in Nigeria have resorted to the use 350 of petrol/diesel generators as a result of the inadequate power supply in the country. The unstable 351 power supply also explains the availability of rechargeable lanterns in some households as they 352 are mostly used during grid electricity outages.

353 Heating, lighting, leisure and air conditioner accounts for the highest (24.8\%) of energy 354 consumption in the study locations. Heating observed in the field survey is mainly composed of 355 the source of heating for cooking (hot plate, microwave oven, boiling ring, electric kettle, rice 356 cooker, kerosene and LPG cook stoves) as compared to boiler for residential heating in the 357 temperate regions of the world. Lighting includes the use of compact fluorescent, fluorescent 358 lamps, and incandescent lamps. Leisure refers to entertainment (the use of audio, video and 359 television for leisure, and charging of mobile phones and PCs- desktops and laptops). Air 360 conditioner for cooling in the studied areas have higher power ratings compared to fans. Higher 361 rates of energy consumption from heating, lighting, leisure and cooling recorded from studied 362 areas can be attributed to location (urban) and socioeconomic status of the residents. This is 
363 consistent with the findings of Emagbetere and Oreko (2016); and Olaniyan et al. (2018). High

364 energy consumption from luxurious and high power rating electrical appliances are prevalent

365 with urban dwellers like those in Lagos city compared to rural dwellers (Olaniyan et al., 2018).

366 This is due to their socioeconomic status and the advantage of having longer hours of electricity

367 supply from the grid system compared to those in the rural areas. Emagbetere and Oreko (2016)

368 reported that the choice of the source of energy used for cooking in Lagos State, Nigeria is

369 influenced by the level of income, education and the job of the individual. The average weekly

370 consumption of diesel, kerosene, and candles in study locations is about 28 litres, 1 litre and 7

371 bars of candles respectively. In some cases, consumption differs with building types and utility.

372 The average weekly consumption of diesel for traditional court buildings is equal to 12 litres,

373 duplex and 'Face-me-I-face-you' is equal to 14 litres, single family bungalow and flat dwellings

374 is equal to 28 litres. It was observed that traditional court buildings use more kerosene (average

375 of 7 litres per week) followed by duplex (average of 5 litres per week) compared to 1 litre used

376 in single family bungalow and flat buildings. The highest number of candles (average of 20 bars

377 per week) was recorded from flat buildings. The use of kerosene lamps and candles in

378 households could be attributed to the high cost of running a diesel generator. Consequently, the

379 diesel generator would not be used for 24 hours of the day and residents will need to use

380 kerosene lamps so as to keep the home illuminated at night after the generator has been turned

381 off. Power consumption in the study locations are greatly increased during dry seasons and

382 festive periods. This indicates that meteorological conditions represents an important factor that

383 influences electricity load of dwellings and our findings concord with that of Novoselac et al.

384 (2014) who reported a variation of daily electricity loads between seasons. Similarly, Fotsing et

385 al. (2014) reported the occurrence of minimum and maximum load in Cameroon in the month of 
August (wet season) and December (hot season) respectively. As attested by Aldossary et al.

387 (2014), more electricity is needed for air conditioning during periods of higher temperatures.

\subsection{PV-system for maximum and minimum loads of buildings}

389

390

391

392

393 404 in the electric load of the dwellings. and $2 \%$ inflation rate. battery and lowest converter of $0.6 \mathrm{~kW}$.

The results of the HOMER Pro simulations of the PV-systems for meeting the minimum and maximum loads of each building type according to each LGA is presented in Table 5. The technical specifications presented in Table 5 are for the base case scenario: $0 \%$ capacity shortage, $40 \%$ battery minimum state of charge, 25 years PV-system's lifetime, 5\% discount rate

With regards to the PV-systems designed for the maximum loads of buildings, the largest size of PV-array $(78 \mathrm{~kW})$ will be required for "Face-me-I-face-you" building type in Alimosho LGA with $176 \mathrm{kWh}$ lead acid battery, $20 \mathrm{~kW}$ converter. On the other hand, traditional court buildings in Kosofe LGA will require the smallest size of PV-system array $(0.6 \mathrm{~kW})$ with $4 \mathrm{kWh}$ lead acid

For solar PV-systems designed for the minimum loads, the largest size of PV-system array, lead acid battery and converter ( $22 \mathrm{~kW}, 80 \mathrm{kWh}$, and $4.6 \mathrm{~kW}$ respectively) will be required for duplex in Alimosho LGA. Conversely, 'Face -me-I- face -you' in Kosofe LGA will require the smallest size of PV-system array, lead acid battery and converter $(0.2 \mathrm{~kW}, 2 \mathrm{kWh}$, and $0.1 \mathrm{~kW}$ respectively). A variation in the capacity of the system components is a function of the variation

Table 5: Specifications for PV-system components

\begin{tabular}{|l|l|l|l|l|}
\hline Building type & LGA & $\begin{array}{l}\text { PV-array } \\
(\mathrm{kW})\end{array}$ & $\begin{array}{l}\text { 1 kWh lead acid } \\
\text { battery }\end{array}$ & Converter (kW) \\
\hline \multicolumn{3}{|c|}{ PV DESIGN FOR MAXIMUM LOAD OF BUILDINGS } \\
\hline
\end{tabular}




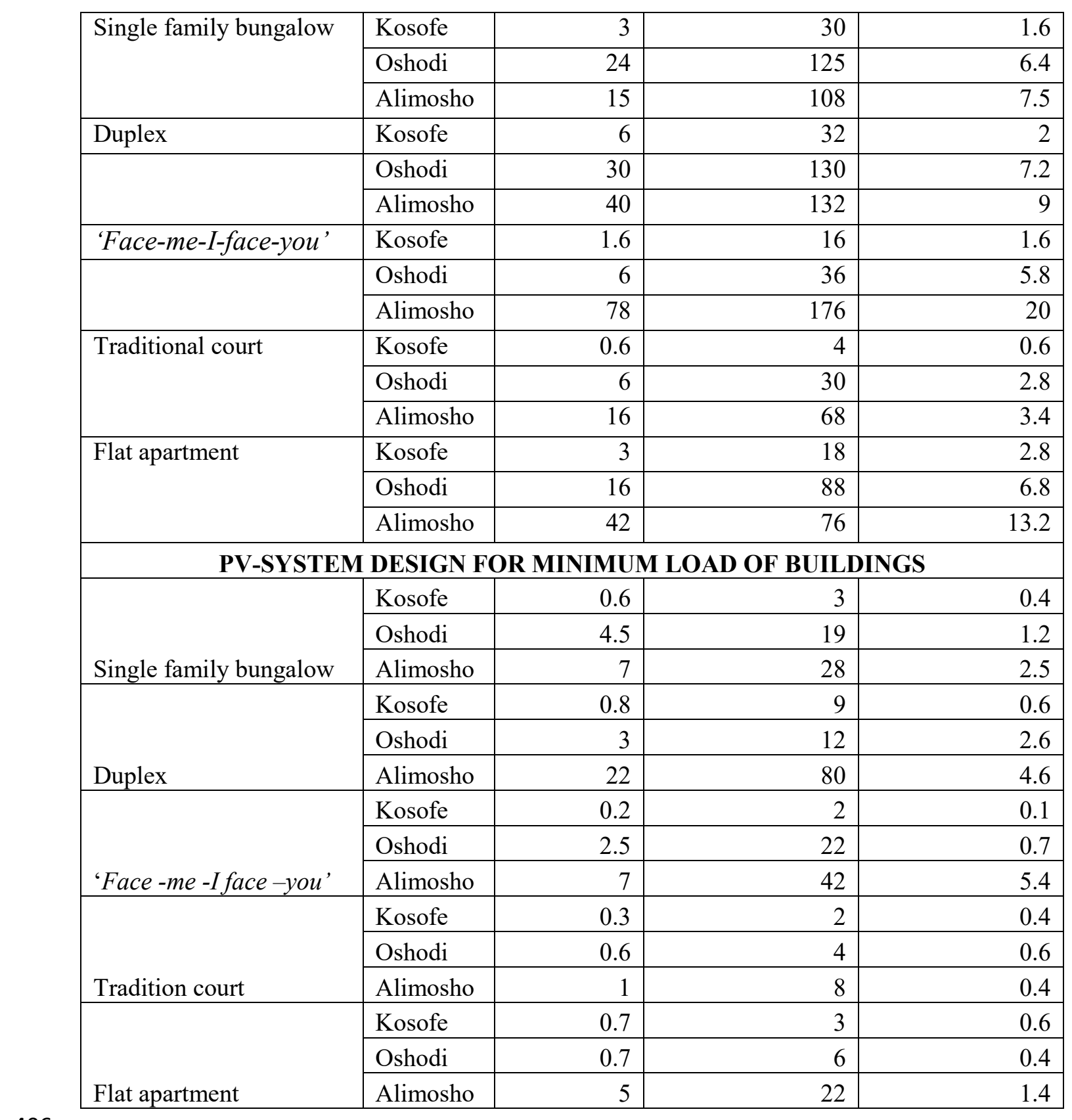

408 The computed required PV-system array area for the different buildings is presented in Table 6.

409 From literature (Eruola et al., 2010; Fagbemi, 2011), the rooftop area of typical buildings in

410 Southwest Nigeria are as follows: single family bungalow $\left(332.12 \mathrm{~m}^{2}\right)$; duplex $\left(218.3 \mathrm{~m}^{2}\right)$; Face-

411 me-I-face-you' (156.78 $\left.\mathrm{m}^{2}\right)$; traditional court $\left(282.24 \mathrm{~m}^{2}\right)$; and flat apartment $\left(280.72 \mathrm{~m}^{2}\right)$. 
412 Comparing the PV-system array area obtained from our study to the rooftop area of the different

413 types of building obtained from the literature, the building types can accommodate their

414 respective PV-system array on their rooftops except for the Face-me-I-face-you' building in

415 Alimosho LGA. This implies that the rooftop area is an important factor that should be taken

416 into consideration in the assessment of the technical feasibility for the application of solar PV-

417 systems in the onsite generation and use of electricity in residential buildings. Although most of

418 the buildings have roof area large enough to accommodate the PV-array, shading of the PV

419 panelsy on the rooftops could result to system losses thereby affecting the capacity of the system

420 to meet the load of the building. Our computation assumes that the PV-systems installed in the

421 buildings would have minimal shading.

422 Table 6: Required PV-system array area for the different buildings

\begin{tabular}{|c|c|c|c|c|}
\hline Building type & LGA & $\begin{array}{l}\text { PV-system array } \\
\text { area (in } \mathrm{m}^{2} \text { )-low } \\
\text { loads }\end{array}$ & $\begin{array}{l}\text { PV-system array } \\
\text { area }\left(\text { in } \mathrm{m}^{2}\right) \text {-High } \\
\text { loads }\end{array}$ & $\begin{array}{l}\text { Roof area }\left(\mathrm{m}^{2}\right) \text { of } \\
\text { building }\end{array}$ \\
\hline \multirow{3}{*}{ Single family bungalow } & Kosofe & 1.69 & 12.44 & \multirow[b]{3}{*}{332.12} \\
\hline & Oshodi & 13.30 & 76.15 & \\
\hline & Alimosho & 20.71 & 50.38 & \\
\hline \multirow{3}{*}{ Duplex } & Kosofe & 3.32 & 17.57 & \multirow[b]{3}{*}{218.3} \\
\hline & Oshodi & 8.73 & 98.87 & \\
\hline & Alimosho & 53.24 & 93.69 & \\
\hline \multirow{3}{*}{ 'Face-me-I-face-you' } & Kosofe & 0.79 & 6.41 & \multirow[b]{3}{*}{156.78} \\
\hline & Oshodi & 9.63 & 16.85 & \\
\hline & Alimosho & 26.35 & 187.63 & \\
\hline \multirow{3}{*}{ Traditional court } & Kosofe & 0.89 & 1.94 & \multirow[b]{3}{*}{282.24} \\
\hline & Oshodi & 2.37 & 18.84 & \\
\hline & Alimosho & 4.37 & 46.19 & \\
\hline \multirow{3}{*}{ Flat apartment } & Kosofe & 2.12 & 9.32 & \multirow[t]{3}{*}{280.72} \\
\hline & Oshodi & 2.50 & 47.50 & \\
\hline & Alimosho & 14.78 & 65.83 & \\
\hline
\end{tabular}


424 Overall, reducing the load of the buildings would reduce the PV array size and consequently, the

425 required rooftop area. Observations from field survey revealed that power ratings of appliances

426 of the residents is a major contributor to electric loads. As pointed out by Edomah and Nwaubani

427 (2014), it is imperative that minimum efficiency standards for domestic appliances be set in

428 Lagos since residential energy consumption accounts for $70 \%$ power demand in the state.

429 Implementing policies or enforcing minimum standards for appliances will influence consumer

430 behaviour to adopting energy efficient appliances and also prohibit the importation, production

431 and sales of energy- consuming appliances. However, the Nigerian governance system on energy

432 efficiency of residential electrical appliances is weakly formulated due to lack of policy, non-

433 engagement of the key stakeholders (households) in the design of agenda and participation in

434 decision-making processes, shortage of allocated resources, and the over-lapping work of 435 different governmental organizations (Gana \& Hoppe, 2017). Therefore, awareness/sensitization 436 of the residents on the adoption of energy efficient appliances in their homes can be an effective 437 way to reduce electric loads.

\section{Sensitivity analysis for technical specifications for system components}

439 Sensitivity analysis was conducted on the annual capacity shortage $(5 \%, 10 \%$ and $15 \%)$ and the 440 minimum battery state of charge (30\%). The effect of varying annual capacity shortage and 441 minimum battery state of charge on the technical specifications of the systems designed for the 442 minimum loads of the single family bungalow building type is presented in Table 7 (See 443 Appendix B in Data in Brief for other types of buildings).

444 An overview of the results of the sensitivity analysis shows that increase in maximum annual 445 capacity shortage (from $0-15 \%$ ) will lead to decrease in the size of PV-system array and lead 
446 acid battery. This is supported by the claim of Enongene (2016) that an increase in capacity

447 shortage decreases the amount of the load of the dwelling that must be met by the system and

448 consequently a reduction in the PV-system array and battery bank. However, the case is different

449 for lead acid battery in Alimosho (increase between 5- $10 \%$ and subsequent decrease at $15 \%$ ).

450 For minimum battery state of charge (at sensitivity value of $30 \%$ ), results reveal that Alimosho

451 will require the largest size of PV-system array and lead acid battery ( $7 \mathrm{~kW}$ and $24 \mathrm{kWh}$

452 respectively). In contrast, Kosofe will require the smallest size of PV-system array $(0.5 \mathrm{~kW})$ and

453 lead acid battery $(3 \mathrm{kWh})$.

454 Table 7: Effects of minimum battery state of charge and capacity shortage on system components 455 (for minimum loads of single family bungalow building type)

\begin{tabular}{|c|c|c|c|c|}
\hline LGA & Sensitivity value $(\%)$ & $\begin{array}{l}\text { PV-system array } \\
(\mathrm{kW})\end{array}$ & $\begin{array}{l}1 \mathrm{kWh} \text { lead } \\
\text { acid battery }\end{array}$ & $\begin{array}{l}\text { PV-system power } \\
\text { output (kWh/year) }\end{array}$ \\
\hline \multicolumn{5}{|c|}{ Sensitivity variable: Maximum annual capacity shortage } \\
\hline \multirow{4}{*}{ Kosofe } & 0 & 0.6 & 3 & 839 \\
\hline & 5 & 0.3 & 3 & 419 \\
\hline & 10 & 0.3 & 2 & 419 \\
\hline & 15 & 0.3 & 2 & 419 \\
\hline \multirow{4}{*}{ Oshodi } & 0 & 4.5 & 19 & 6291 \\
\hline & 5 & 2.5 & 12 & 3495 \\
\hline & 10 & 2 & 12 & 2796 \\
\hline & 15 & 2 & 8 & 2796 \\
\hline \multirow{4}{*}{ Alimosho } & 0 & 7 & 28 & 9787 \\
\hline & 5 & 4 & 20 & 5593 \\
\hline & 10 & 3 & 22 & 4194 \\
\hline & 15 & 3 & 14 & 4194 \\
\hline \multicolumn{5}{|c|}{ Sensitivity variable: Minimum battery state of charge } \\
\hline \multirow[b]{2}{*}{ Kosofe } & $40 \%$ & 0.6 & 3 & 839 \\
\hline & $30 \%$ & 0.5 & 3 & 699 \\
\hline \multirow[b]{2}{*}{ Oshodi } & $40 \%$ & 4.5 & 19 & 6291 \\
\hline & $30 \%$ & 4 & 19 & 5592 \\
\hline \multirow[b]{2}{*}{ Alimosho } & $40 \%$ & 7 & 28 & 9787 \\
\hline & $30 \%$ & 7 & 24 & 9787 \\
\hline
\end{tabular}




\subsection{Economic analysis}

458 The economic analysis results of the PV-systems in terms of the LCOE (for the base case

459 scenario) are presented in Table 8. The LCOE of electricity of the designed systems (30 systems)

460 for the base case scenario ranges from $0.398 \mathrm{USD} / \mathrm{kWh}$ (Oshodi, maximum load for duplex

461 building) to $0.743 \mathrm{USD} / \mathrm{kWh}$ (Alimosho, maximum load for flat apartment). This wide variation

462 in the LCOE could be due to the fact that there exists a difference in the nature of the loads of the

463 buildings. There are some buildings with very high loads that occur after sunshine hours and

464 such buildings require a large battery bank for energy storage to support these high night loads,

465 culminating in higher LCOE. The values of the LCOE obtained in this study are higher

466 compared to USD $0.098 / \mathrm{kWh}$ cost of electricity from the grid power system in some locations in

467 Nigeria. This supports the claim of Baurzhan and Jenkins (2016) that solar PV is unaffordable to

468 rural households in Sub Sahara Africa from an economic and financial perspective. Such

469 households are unable to afford the up-front capital cost of the system due to low or irregular

470 income. The range of LCOE obtained from this study is higher compared to that $(0.206$

$471 \mathrm{USD} / \mathrm{kWh}$ to $0.502 \mathrm{USD} / \mathrm{kWh}$ ) obtained by Okoye et al. (2016) for selected cities (Onitsha,

472 Kano and Lagos) in Nigeria. The LCOE obtained for the city of Lagos by the authors were 0.417

473 and $0.495 \mathrm{USD} / \mathrm{kWh}$. Meanwhile the study by Okoye et al. (2016) considered all the components

474 of a stand-alone PV system as our study, their study used an estimated energy load data of a

475 hypothetical building (typical large household in Onitsha) for the design of the PV-system using

476 intuitive and numerical methods while in our case, household specific electricity load data for 50

477 buildings (covering five building types) were considered in the simulation of the PV systems

478 using the HOMER Pro software. Hence, the disparity that exists between the range of LCOE

479 from our study and theirs is not unexpected. Studies by Ohijeagbon \& Ajayi (2014) estimated the 
480 unit cost of electricity generated from diesel generators in Nigeria at $0.62 \mathrm{USD} / \mathrm{kWh}$. Only one

481 of the thirty systems designed had a unit cost of electricity that was superior to $0.62 \mathrm{USD} / \mathrm{kWh}$.

482 Hence, PV-systems are more economically viable for use as stand-alone systems compared to

483 diesel generators. While this could constitute an incentive for the adoption of solar PV, the 484 viability of households to adopt solar PV will depend on their ability to afford the associated up485 front capital cost. The unit cost of electricity from PV-systems obtained from this study could be 486 lowered if the Nigerian government ensures an enabling condition that will bolster the adoption 487 of the technology.

Table 8: Results of the economic analysis of the PV-systems

\begin{tabular}{|l|l|c|c|}
\hline \multirow{2}{*}{ Building type } & \multirow{2}{*}{ LGA } & \multicolumn{2}{|c|}{ LCOE (USD/kWh) } \\
\cline { 3 - 4 } & & Maximum loads & Minimum loads \\
\hline \multirow{5}{*}{ Duplex } & Kosofe & 0.497 & 0.552 \\
\cline { 2 - 4 } & Oshodi & 0.398 & 0.459 \\
\cline { 2 - 4 } & Alimosho & 0.411 & 0.502 \\
\hline \multirow{5}{*}{ Face -me -I -face -you' } & Kosofe & 0.508 & 0.529 \\
\cline { 2 - 4 } & Oshodi & 0.452 & 0.439 \\
\cline { 2 - 4 } & Klimosho & 0.513 & 0.432 \\
\cline { 2 - 4 } & Oosofe & 0.538 & 0.531 \\
\cline { 2 - 4 } & Oshodi & 0.571 & 0.498 \\
\cline { 2 - 4 } & Alimosho & 0.429 & 0.422 \\
\hline \multirow{5}{*}{ Fraditional court } & Kosofe & 0.54 & 0.575 \\
\cline { 2 - 4 } & Oshodi & 0.453 & 0.43 \\
\cline { 2 - 4 } & Alimosho & 0.45 & 0.417 \\
\hline & Kosofe & 0.547 & 0.449 \\
\cline { 2 - 4 } & Oshodi & 0.501 & 0.533 \\
\cline { 2 - 4 } & Alimosho & 0.743 & 0.488 \\
\hline
\end{tabular}

492 Using the duplex building type as an example, the effect of the inflation rate and discount rate on 493 the LCOE is presented in Figure 2. Increasing the discount rate from $5 \%$ to $10 \%$ culminates in an 
494 increase in the LCOE while an increase in the inflation rate from $2 \%$ to $5 \%$ reduces the LCOE. 495 Using the duplex building type (maximum load) for the Kosofe LGA as an example, an increase 496 in the discount rate from $5 \%$ to $10 \%$ results in an increase in the LCOE from $0.497 \mathrm{USD} / \mathrm{kWh}$ to $4970.706 \mathrm{USD} / \mathrm{kWh}$. The other building types for the different LGA observed the same trend 498 (Appendix C - see Data in Brief). Ayompe and Duffy (2014) witnessed a similar increasing trend 499 of the LCOE as a result of an increase in the discount rate. According to Enongene (2016), as the 500 discount rate increases, the present value of future cash flows of the PV-system is decreased 501 culminating in an increased LCOE of the system.
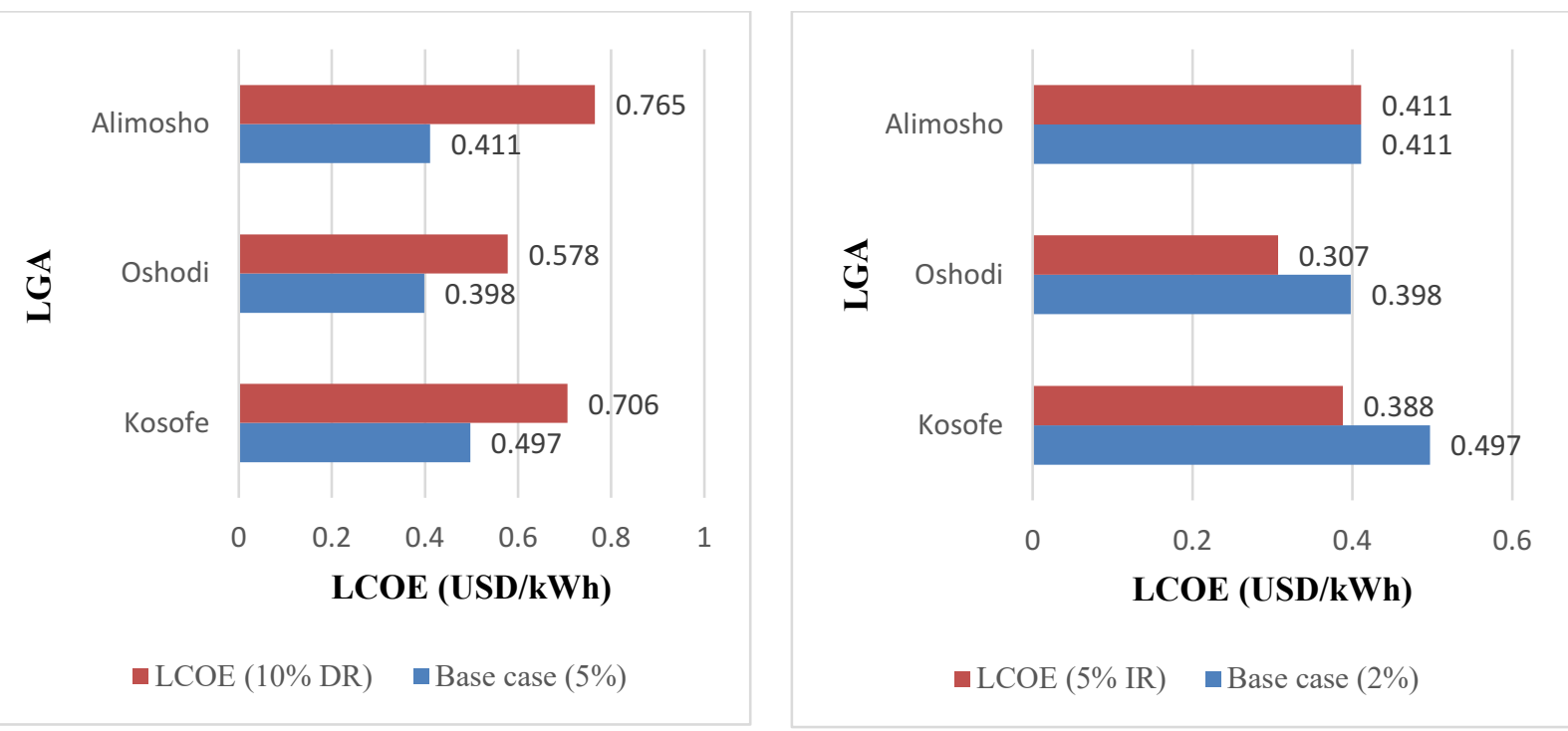

Figure 2: Influence of discount rate (left) and inflation rate (right) on the LCOE for the system 504 designed for the maximum load for the duplex building type. An increase in the maximum annual capacity shortage decreases the LCOE of the systems. The LCOE for the flat apartment building type (maximum load) for Kosofe decreased from 0.547 $\mathrm{USD} / \mathrm{kWh}(0 \%$ capacity shortage) to $0.459 \mathrm{USD} / \mathrm{kWh}(15 \%$ capacity shortage) as can be verified

508 from Figure 3. Such a reduction in LCOE could be explained by the fact that, as the capacity 509 shortage is increased, the proportion of the building's load to be left unmet increases and 510 consequently, load culminating in an increase in LCOE of the system (such as high load 
511 occurring after sunshine hours) is left unserved. The reduction in LCOE associated with an 512 increase in capacity shortage is indicative of the fact that hybrid PV-systems are more 513 economically viable compared to the stand-alone ones. The effect of capacity shortage for the 514 other building types for the different LGAs is presented in Appendix C. A remarkable difference 515 is observed between the LCOE at 0\% capacity shortage and 5\% capacity shortage. Using Kosofe 516 as an example (Figure 3), the LCOE (USD/kWh) at $0 \%$ and $5 \%$ capacity shortage is 0.547 and 5170.461 respectively culminating in a difference of 0.088 . This difference is large when compared 518 to 0.002 which represents the difference in the LCOE between $5 \%(0.461)$ and $15 \%(0.459)$.

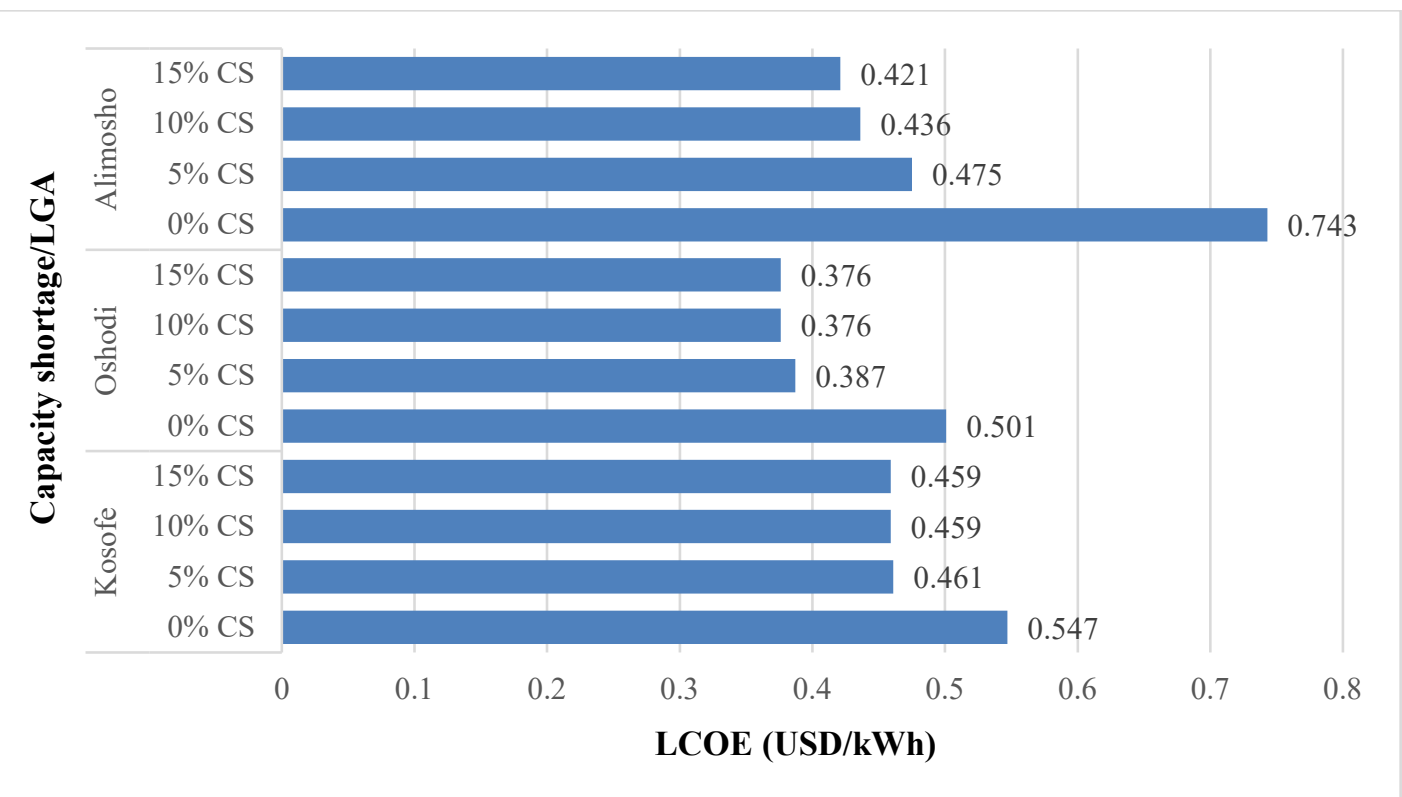

Figure 3: Influence of capacity shortage on LCOE for the maximum load of flat apartments

522 Regarding the effect on the PV-system lifetime on the LCOE, the PV-system lifetime is 523 inversely proportional to the LCOE of the system. A decrease in the PV-system's lifetime from 52425 to 20 years increases the LCOE of the system while the reverse is true for an increase in the 525 PV-system's lifetime from 25 years to 30 years as presented in Figure 4 for the case of flat- 
apartment (See Appendix C for details for the other buildings types). As reported by Enongene

527 (2016), increase in the lifetime of the PV-systems translates into more energy generated by the 528 system for the same initial capital cost and this explains a decrease in the system's LCOE.

529

530

531

532

533

534

535

536

537

538

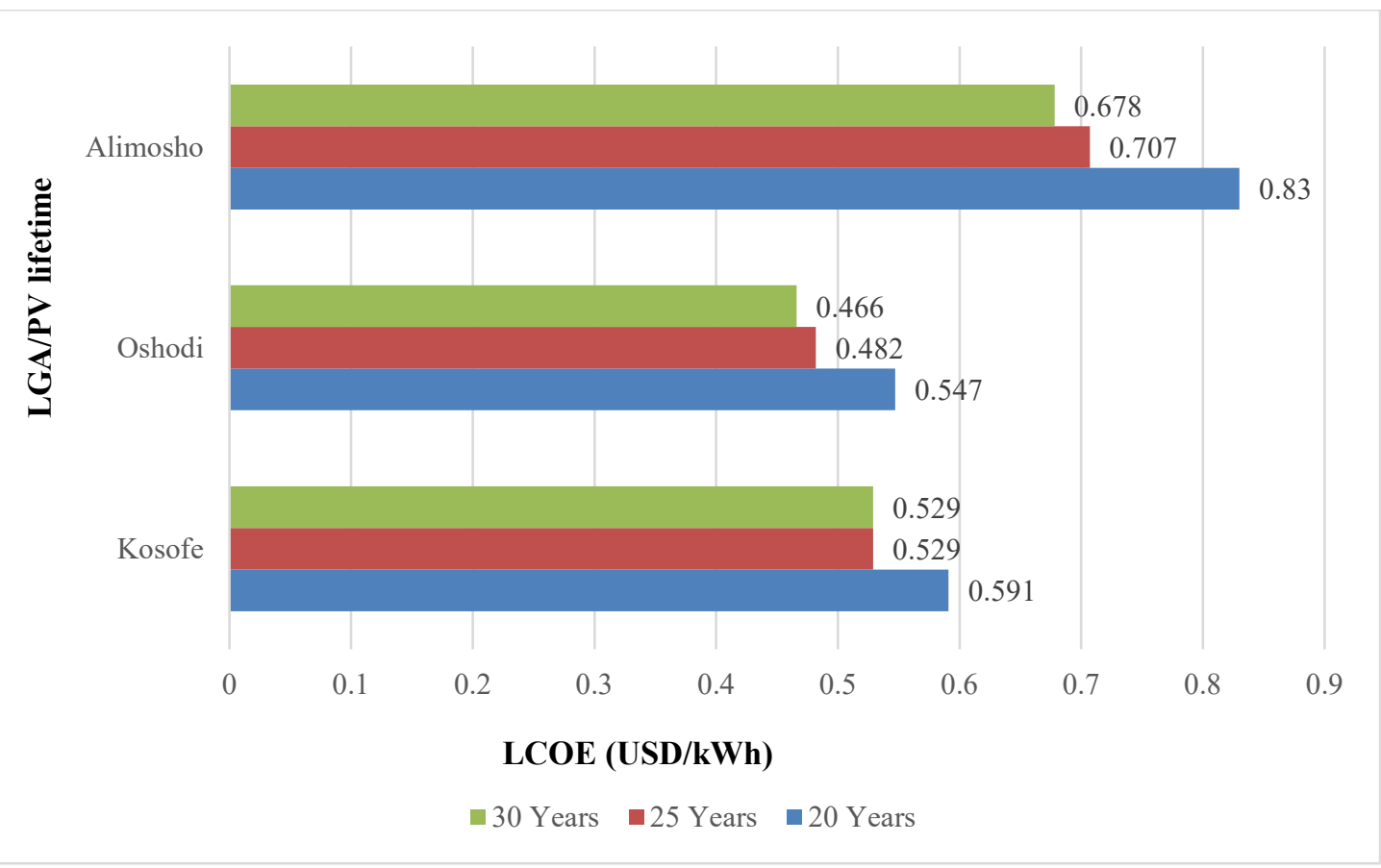

Figure 4: Effect of PV-system lifetime on the LCOE for the system designed for the maximum load for the Flat-apartment building type

\subsection{Environmental potential of the PV-systems}

The environmental analysis associated with the use of solar PV-system generated electricity for meeting the entire load of the buildings $(0 \%$ capacity shortage $)$ is presented in Table 9 . The emission reduction associated with the use of electricity from the PV-system varies with different buildings. Pertaining to the high loads, the annual emission reduction varies from 76.90 (Traditional Court, Kosofe) to $7456.44 \mathrm{kgCO}_{2} \mathrm{eq}$ ('Face- me $-I$ - face -you', Alimosho). For the low loads, the emission reduction varies from 35.95 (traditional court, Kosofe) to 2115.95 $\mathrm{kgCO}_{2}$ eq (duplex, Alimosho). This observed variation is due to the existence of differences in the daily loads of the buildings. In a nutshell, the use of electricity generated from PV-system in 
541 each building reduces annual emissions by $63.2 \%$ compared to the business-as-usual scenario in

542 which case the buildings would solely rely on the grid to satisfy their respective electricity

543 requirements.

544 Table 9: Annual emission reductions (kgCO2eq) associated with the use of PV-system 545 generated electricity in buildings

\begin{tabular}{|l|r|r|r|}
\hline Building types & \multicolumn{1}{|l|}{ Kosofe } & \multicolumn{1}{l|}{ Oshodi } & \multicolumn{1}{l|}{ Alimosho } \\
\hline \multicolumn{4}{|c|}{ Maximum loads } \\
\hline Single family bungalow & 493.56 & 3025.76 & 2001.86 \\
\hline Flat Apartment & 370.58 & 1887.20 & 2615.87 \\
\hline 'Face- me-I-face-you' & 254.56 & 3673.65 & 7456.44 \\
\hline Duplex & 697.97 & 3930.15 & 3723.08 \\
\hline Traditional court & 76.90 & 748.85 & 1830.43 \\
\hline \multicolumn{4}{|c|}{ Minimum loads } \\
\hline Single family bungalow & 66.46 & 528.95 & 822.69 \\
\hline Flat apartment & 84.29 & 99.95 & 587.58 \\
\hline 'Face -me-I-face-you & 31.24 & 382.61 & 1394.63 \\
\hline Duplex & 132.49 & 347.39 & 2115.95 \\
\hline Traditional court & 35.95 & 71.32 & 173.88 \\
\hline
\end{tabular}

\section{Conclusion and Policy implications}

548 This study focused on the assessment of the technical, economic and environmental potential of 549 onsite PV-systems for generating electricity in different residential building types in the Lagos Metropolitan Area of Nigeria.

551 The computed energy results of the study for the maximum load of buildings for the base case 552 scenario revealed the PV array, lead acid battery and the converter (inverter) of the PV-systems 553 to be in the following range: 0.3 to $76 \mathrm{~kW} ; 2$ to $176 \mathrm{kWh}$; and 0.1 to $13.2 \mathrm{~kW}$ respectively. For 554 the minimum load of the buildings, the results of the PV array, lead acid battery and converter of 555 the system were found to be in the following order: 0.3 to $7 \mathrm{~kW} ; 2$ to $80 \mathrm{kWh} ; 0.1$ to $5.4 \mathrm{~kW}$ 556 respectively. Results of the economic analysis revealed a LCOE of the systems in the range of 
$5570.398 \mathrm{USD} / \mathrm{kWh}$ to $0.743 \mathrm{USD} / \mathrm{kWh}$ for maximum loads and $0.422 \mathrm{USD} / \mathrm{kWh}$ to 0.552

$558 \mathrm{USD} / \mathrm{kWh}$ for minimum loads. The use of PV-system generated electricity in the dwellings have

559 potential for an annual reduction of greenhouse gas emissions in the range of $76.90 \mathrm{gCO}_{2} \mathrm{eq}$ to

$5607456.44 \mathrm{kgCO}_{2} \mathrm{eq}$ (for maximum loads) and $31.24 \mathrm{gCO}_{2}$ eq to $2115.95 \mathrm{kgCO}_{2} \mathrm{eq}$ (for minimum

561 loads). Generally, from a technical perspective, solar PV-systems have the potential for use as a

562 stand-alone source of electrical energy in the different categories of residential buildings in

563 Lagos, Nigeria. While the LCOE for the PV-systems is lower than that of diesel generator used

564 by households, it is high compared to the LCOE of the grid.

565 The promotion of an enabling environment for the adoption and use of solar PV-system in 566 residential buildings will support the attainment of Nigeria's mitigation target spelt out in the 567 country's nationally determined contribution (NDC). However, just creating a favourable 568 environment for the adoption and use of PV-systems may not constitute a solution to all 569 dwellings. For instance, this study revealed a building with high electric load which requires a 570 PV array size greater than the available rooftop area. For such a building, a reduction in the 571 electric load through energy efficiency measures would reduce the size of the PV-array, 572 rendering the rooftop adequate to accommodate the PV array. Therefore, there is need for the 573 government of Nigeria to use a mix of energy policy options that can support the deployment and 574 uptake of solar PV-systems in the country on the one hand, while reducing residential energy 575 consumption through the promotion of energy efficiency on the other hand.

576 Future research should investigate periods during the day which power outages occur and based 577 on this information, explore the possibility of designing a solar PV-system grid-connected hybrid 578 system for the residential buildings. 


\section{Acknowledgement}

580 The authors would like to thank the Economic Community of West African States (ECOWAS)

581 Centre for Renewable Energy and Energy Efficiency (ECREEE) for funding this study. We

582 would also like to thank Monica Maduekwe, Yuri Lima Handem and Francis Kemausuor for

583 reviewing the manuscript. Lastly, we thank Ana Apueyo for developing a poster from this work

584 for presentation at the ECOWAS Centre for Renewable Energy and Energy Efficiency

585 (ECREEE) $2^{\text {nd }}$ Edition of the ECOWAS Sustainable Energy Forum (ESEF2018) from 13 -15

586 November 2018 at the Radisson Blu Hotel in Dakar, Senegal.

587

588 


\section{References}

590 Abanda, F., Manjia, M., Enongene, K., Tah, J., \& Pettang, C. (2016). A feasibility study of a 591 residential photovoltaic system in Cameroon. Sustainable Energy Technologies and Assessments, $592 \quad 17,38-49$.

593 Adama, O. (2017). Urban imaginaries: funding mega infrastructure projects in Lagos, Nigeria.

594 GeoJournal. doi: 10.1007/s10708-016-9761-8

595 Adaramola, M. S. (2014). Viability of grid-connected solar PV energy system in Jos, Nigeria.

596 International Journal of Electrical Power \& Energy Systems, 61, 64-69.

597 Adaramola, M. S., Paul, S. S., \& Oyewola, O. M. (2014). Assessment of decentralized hybrid PV

598 solar-diesel power system for applications in Northern part of Nigeria. Energy for Sustainable

599 Development, 19, 72-82.

600 Adejumobi, I., Adebisi, O., \& Oyejide, S. (2013). Developing small hydropower potentials for 601 rural electrification. International Journal of Research and Reviews in Applied Sciences, 17(1), $602 \quad 105-110$.

603 Aldossary, N. A., Rezgui, Y. \& Kwan, A. (2014). Domestic energy consumption patterns in a hot 604 and arid climate: A multiple-case study analysis. Renewable Energy 62, 369-378.

605 Ahemen, I., Amah, A. N., \& Agada, P. O. (2016). A survey of power supply and lighting 606 patterns in North Central Nigeria -The energy saving potentials through efficient lighting 607 systems. Energy and Buildings, 133, 770-776. doi:

608 http://dx.doi.org/10.1016/j.enbuild.2016.10.029

609 Ajao, K., Oladosu, O., \& Popoola, O. (2011). Using HOMER power optimization software for 610 cost benefit analysis of hybrid-solar power generation relative to utility cost in Nigeria.

611 International Journal of Research and Reviews in Applied Sciences, 7(1), 14.

612 Ajayi, O. O., \& Ajayi, O. O. (2013). Nigeria's energy policy: Inferences, analysis and legal ethics 613 toward RE development. Energy Policy, 60, 61-67. doi:

614 http://dx.doi.org/10.1016/j.enpol.2013.05.095

615 Akinyele, D., Rayudu, R., \& Nair, N. (2017). Life cycle impact assessment of photovoltaic 616 power generation from crystalline silicon-based solar modules in Nigeria. Renewable Energy, $617101,537-549$.

618 Akorede, M., Ibrahim, O., Amuda, S., Otuoze, A., \& Olufeagba, B. (2017). Current status and 619 outlook of renewable energy development in Nigeria. Nigerian Journal of Technology, 36(1), $620 \quad 196-212$. 
Akpan, U. S., Isihak, S. R., \& Udoakah, Y.-O. N. (2013). Electricity access in Nigeria: Viability of off-grid photovoltaic system. Paper presented at the AFRICON, 2013.

Akuru, U. B., Onukwube, I. E., Okoro, O. I., \& Obe, E. S. (2017). Towards 100\% renewable energy in Nigeria. Renewable and Sustainable Energy Reviews. doi: http://dx.doi.org/10.1016/j.rser.2016.12.123

Ayompe, L. M. and Duffy, A. (2014). An assessment of the energy generation potential of photovoltaic systems in Cameroon using satellite-derived solar radiation datasets. Sustainable Energy Technologies and Assessments 7, 257-264.

Ayodele, T. R. \& Ogunjuyigbe, A. S. O. (2015). Increasing household solar energy penetration through load partitioning based on quality of life: The case study of Nigeria. Sustainable Cities and Society, 18, $21-31$.

Azodo, A. P. (2014). Electric power supply, main source and backing: A survey of residential utilization features. International Journal of Research Studies in Management, 3(2).

Bamisile, O., Dagbasi, M., Babatunde, A., \& Ayodele, O. (2017). A review of renewable energy potential in Nigeria; solar power development over the years. Engineering and Applied Science Research, 44(4), 242-248.

Baurzhan, S. \& Jenkins, P. (2016). Off-grid solar PV: Is it an affordable or appropriate solution for rural electrification in Sub-Saharan African countries? Renewable and Sustainable Energy Reviews, 60, 1405-1418.

Brander, M., Sood, A., Wylie, C., Haughton, A. \& Lovell, J. (2011). Technical Paper | Electricity-specific emission factors for grid electricity. Retrieved from: https://ecometrica.com/assets/Electricity-specific-emission-factors-for-grid-electricity.pdf Bukar, A. L., Modu, B., Gwoma, Z. M., Mustapha, M., Buji, A. B., Lawan, M. B., Mai, K. B. (2017). Economic Assessment of a PV/Diesel/Battery Hybrid Energy System for a NonElectrified Remote Village in Nigeria. European Journal of Engineering Research and Science, 2(1).

Diemuodeke, E. O., Hamilton, S., \& Addo, A. (2016). Multi-criteria assessment of hybrid renewable energy systems for Nigeria's coastline communities. Energy, Sustainability and Society, 6(1), 26. doi: 10.1186/s13705-016-0092-x

Edomah, N., \& Nwaubani, S. (2014). Energy security challenges in developing African mega cities: the Lagos experience. Built Environment, 1-9.

Elum, Z. A., Modise, D. M., \& Nhamo, G. (2016). Climate change mitigation: the potential of agriculture as a renewable energy source in Nigeria. Environmental Science and Pollution Research, 1-14. doi: 10.1007/s11356-016-8187-7 
Emagbetere, E., Odia, J., \& Oreko, B.U. (2016). Assessment of Household Energy Utilized For Cooking In Ikeja, Lagos State, Nigeria. Nigerian Journal of Technology (NIJOTECH), 35 (4), $796-804$.

Enongene, K. E. (2016). Feasibility of a solar photo-voltaic system as an energy source for lighting in grid-connected residential buildings in Cameroon: Case study of Buea (master's thesis, Massey University, Palmerston North, New Zealand).

Enongene, K. E., Murray, P., Holland, J. \& Abanda, F. H. (2017). Energy savings and economic benefits of transition towards efficient lighting in residential buildings in Cameroon. Journal of Renewable and Sustainable Energy Reviews, 78, 731-742.

Fadare, D. (2009). Modelling of solar energy potential in Nigeria using an artificial neural network model. Applied Energy, 86(9), 1410-1422.

Fotsing, F. I. M., Njomo, D. \& Tchinda, Rene (2014). Analysis of Demand and Supply of Electrical Energy in Cameroon: Influence of Meteorological Parameters on the Monthly Power Peak of South and North Interconnected Electricity Networks. International Journal of Energy and Power Engineering. 3(4), 168-185. doi: 10.11648/j.ijepe.20140304.12

Gana, J., \& Hoppe, T. (2017). Assessment of the Governance System Regarding Adoption of Energy Efficient Appliances by Households in Nigeria. Energies, 10(1), 132.

Giwa, A., Alabi, A., Yusuf, A., \& Olukan, T. (2017). A comprehensive review on biomass and solar energy for sustainable energy generation in Nigeria. Renewable and Sustainable Energy Reviews, 69, 620-641.

Guda, H. A. \& Aliyu, U. O. (2015). Design of a Stand-Alone Photovoltaic System for a Residence in Bauchi. International Journal of Engineering and Technology, 5(1), 34-44. Ikejemba, E. C., \& Schuur, P. (2016). Locating solar and wind parks in South-Eastern Nigeria for maximum population coverage: a multi-step approach. Renewable Energy, 89, 449-462.

International Energy Agency. (2010). Energy Poverty: How to make modern energy access universal? Special early excerpt of the World Energy Outlook (WEO) 2010 for the UN General Assembly on the Millennium Development Goals. (Paris, 2010) p. 9, 20. Available from http://www.iea.org/publications/freepublications/publication/weo-2010---special-report---howto-make-modern-energy-access-universal.html

International Renewable Energy Agency (IRENA), Renewable Energy Target Setting June 2015. International Energy Agency (IEA, 2017). Key World Energy Statistics; International Energy Agency: Paris, France.

Jiboye, A. D. (2014). Significance of house-type as a determinant of residential quality in Osogbo, Southwest Nigeria. Frontiers of Architectural Research, 3(1), 20-27. 
IPCC, 2014: Summary for Policymakers. In: Climate Change 2014: Mitigation of Climate Change. Contribution of Working Group III to the Fifth Assessment Report of the Intergovernmental Panel on Climate Change [Edenhofer, O., R. Pichs-Madruga, Y. Sokona, E. Farahani, S. Kadner, K. Seyboth, A. Adler, I. Baum, S. Brunner, P. Eickemeier, B. Kriemann, J. Savolainen, S. Schlömer, C. von Stechow, T. Zwickel and J.C. Minx (eds.)]. Cambridge University Press, Cambridge, United Kingdom and New York, NY, USA.

Manjia, M. B., Abanda, F. H. \& Pettang C. (2015). Household energy appliances in Cameroon. Environmental Management and Sustainable Development, 4(1): 73-84.

Mellersh N. (2015) A scramble for power - the Nigerian energy crisis explained. Available from https://www.africanlawbusiness.com/news/5679-a-scramble-for-power-the-nigerian-energycrisis-explained

National Bureau of Statistics (NBS, 2016). LSMS-Integrated Surveys on Agriculture General Household Survey Panel 2015/2016. National Bureau of Statistics Abuja, Nigeria.

National Bureau of Statistics (NBS, 2017). Premium Motor Spirit (Petrol) Price Watch for April 2017. National Bureau of Statistics Abuja, Nigeria.

National Population commission Nigeria (2010). 2006 Population and Housing Census. Pp 64. Retrieved from catalog.ihsn.org/index.php/catalog/3340/download/48521

Nigerian Electricity Regulatory Commission (NERC, 2017). How Much Do I Pay for Electricity? Retrieved from http://nerc.gov.ng/index.php/home/consumers/how-much-do-i-payfor-electricity

Njoku, H. (2016). Upper-limit solar photovoltaic power generation: Estimates for 2-axis tracking collectors in Nigeria. Energy, 95, 504-516.

Novoselac, A. Cetin, K. S. \& Tabares-Velasco, P. C. (2014). Appliance daily energy use in new residential buildings: Use profiles and variation in time-of-use. Energy and Buildings, 84, 716726.

Oduwaye, L. (2009). Challenges of Sustainable Physical Planning and Development in Metropolitan Lagos. Journal of Sustainable Development, 2(1), 159-171.

Ofikhenua, J. (2014). Power supply drops to 2,954.51 MW. The Nation Newspaper 14th December 2014. Retrieved from: http://thenationonlineng.net/new/power-supply-drops-2954$\underline{51 \mathrm{mw} /}$

Ogunjuyigbe, A.S.O., Ayodele T.R. \& Oladimeji, O.E. (2016). Management of loads in residential buildings installed with PV system under intermittent solar irradiation using mixed integer linear programming. Journal of Energy \& Buildings, 130 (15), 253-271 
722 Okoye, C. O., \& Taylan, O. (2017). Performance analysis of a solar chimney power plant for 723 rural areas in Nigeria. Renewable Energy, 104, 96-108.

724 Okoye, C. O., Taylan, O., \& Baker, D. K. (2016). Solar energy potentials in strategically located 725 cities in Nigeria: Review, resource assessment and PV system design. Renewable and

726 Sustainable Energy Reviews, 55, 550-566. doi: http://dx.doi.org/10.1016/j.rser.2015.10.154

727 Olaoye, T., Ajilore, T., Akinluwade, K., Omole, F., \& Adetunji, A. (2016). Energy Crisis in 728 Nigeria: Need for Renewable Energy Mix. American Journal of Electrical and Electronic 729 Engineering, 4(1), 1-8.

730 Olaniyi O. (2017) Research: Tackling the energy crisis in Nigeria - a case for solar. Available 731 from https://www.ntusbfcas.com/african-business-insights/content/research-tackling-the-energy732 crisis-in-nigeria-a-case-for-solar

733 Olatomiwa, L., Mekhilef, S., \& Ohunakin, O. S. (2016). Hybrid renewable power supply for 734 rural health clinics (RHC) in six geo-political zones of Nigeria. Sustainable Energy Technologies 735 and Assessments, 13, 1-12.

736 Olaniyan, K., McLellan, B.C., Ogata S., \& Tezuka, T. (2018). Estimating Residential Electricity 737 Consumption in Nigeria to Support Energy Transitions. Sustainability, 10(.;1440), 1-22. 738 doi:10.3390/su10051440

739 Oluseyi, P. O., Babatunde, O. M., \& Babatunde, O. A. (2016). Assessment of energy 740 consumption and carbon footprint from the hotel sector within Lagos, Nigeria. Energy and 741 Buildings, 118, 106-113. doi: http://dx.doi.org/10.1016/j.enbuild.2016.02.046

742 Oparaku, O. (2002). Photovoltaic systems for distributed power supply in Nigeria. Renewable 743 Energy, 25(1), 31-40.

744 Osunmuyiwa, O., \& Kalfagianni, A. (2016). Transitions in unlikely places: Exploring the 745 conditions for renewable energy adoption in Nigeria. Environmental Innovation and Societal 746 Transitions.

747 Otegbulu, A.C. (2011). Economics of Green Design and Environmental Sustainability. Journal 748 of Sustainable Development, 4(2), 240-248.

749 Oyedepo, S. O. (2012). Energy and sustainable development in Nigeria: the way forward. 750 Energy, Sustainability and Society, 2(1), 15.

751 Ozoegwu, C. G., Mgbemene, C. A., \& Ozor, P. A. (2017). The status of solar energy integration 752 and policy in Nigeria. Renewable and Sustainable Energy Reviews, 70, 457-471. doi:

753 http://dx.doi.org/10.1016/j.rser.2016.11.224 
754 Ozoegwu, C. G., Mgbemene, C. A., \& Ozor, P. A. (2017). The status of solar energy integration

755 and policy in Nigeria. Renewable and Sustainable Energy Reviews, 70, 457-471. doi:

756 http://dx.doi.org/10.1016/j.rser.2016.11.224

757 Palm, J. \& Tengvard, M. (2017). Motives for and barriers to household adoption of small-scale 758 production of electricity: examples from Sweden. Sustainability: Science, Practice and Policy, 675915.

760

761

762

763

764

765

766

767

768

769

770

771

772

773

774

775

776

777

778

779

780

781

782

783

784

785

786

787

REN21 (2015). Renewables 2015 global status report. REN21 Secretariat, Paris. Retrieved from: http://www.ren21.net/wp-content/uploads/2015/07/REN12-GSR2015_Onlinebook_low1.pdf

Riti, J. S., \& Shu, Y. (2016). Renewable energy, energy efficiency, and eco-friendly environment (R-E5) in Nigeria. Energy, Sustainability and Society, 6(1), 13. doi: 10.1186/s13705-016-0072-1

Sambo, A. S. (2008a). Matching electricity supply with demand in Nigeria.

International Association of Energy Economics. Fourth Quarter, Pp.32-36.

Retrieved from https://www.iaee.org/documents/newsletterarticles/408sambo.pdf

Sambo, A. S. (2008b). Renewable energy options for the environment and sustainable development in Nigeria. Natl. Work. Energy Invest. Priv. Sect. Particip. Pet. Train. Inst. Warri; 4th-5th June, 2008

Sesan, T. (2008). Status of renewable energy policy and implementation in Nigeria. Institute of Science and Society, Faculty of Social Sciences, Law and Education, University of Nottingham, United Kingdom. Retrieved from: http://www.gbengasesan.com/temidocs/REPStatusNigeria.pdf

Shabaan, M. \& Petinrin, J. O. (2014). Renewable energy potentials in Nigeria: Meeting rural energy needs. Renewable and Sustainable Energy Reviews, 29, 72 - 78.

Sherwani, A. F., Usmani, J. A., \& Varun. (2010). Life cycle assessment of solar PV based electricity generation systems: A review. Renewable and Sustainable Energy Reviews, 14(1), 540-544. doi: http://dx.doi.org/10.1016/j.rser.2009.08.003

Su, M., Chen, C., \& Yang, Z. (2016). Urban energy structure optimization at the sector scale: considering environmental impact based on life cycle assessment. Journal of Cleaner

Production, 112, Part 2, 1464-1474. doi: http://dx.doi.org/10.1016/i.jclepro.2015.01.059

The Nigerian Energy Support Programme (2015). The Nigerian Energy Sector -an Overview with a Special Emphasis on Renewable Energy, Energy Efficiency and Rural Electrification, 2nd Edition, June 2015

United Nations (2015). Goal 7 - Ensure Access to Affordable, Reliable, Sustainable and Modern Energy for All. Retrieved from: https://unchronicle.un.org/article/goal-7-ensure-accessaffordable-reliable-sustainable-and-modern-energy-all 
788 Vasseur, V. \& Kemp, R. (2015). The adoption of PV in the Netherlands: A statistical analysis of 789 adoption factors. Renewable \& Sustainable Energy Reviews, 41, 483-494.

790 Vera, I., \& Langlois, L. (2007). Energy indicators for sustainable development. Energy, 32(6), 791 875-882. doi: http://dx.doi.org/10.1016/j.energy.2006.08.006 